\title{
Effect of mountain gorilla (Gorilla beringei beringei) population growth to their key food plant biomass in Volcanoes National Park, Rwanda.
}

\author{
Samedi M. J.P. ${ }^{1,2}$, Eckardt W. ${ }^{1}$, Derhé M. ${ }^{1}$, Miller M. ${ }^{3}$, Grueter C.C. ${ }^{4}$, Robbins M.M. ${ }^{5}$, Nsabimana D \\ 1.Dian Fossey Gorilla Fund International, PO Box 105 Musanze, Rwanda. \\ 2. University of Rwanda, College of Science and Technology, School of Science, PO Box 4285 Kigali, Rwanda. \\ 3. James Cook University, Cairns, Australia, Smithfield QLD 4878, Australia. \\ 4. The University of Western Australia, School of Anatomy, Physiology and Human Biology, WA6009, Australia \\ 5. Max Planck Institute for Evolutionary Anthropology, Deucher Platz 6, 04103 Leipzig, Germany. ${ }^{2}$
}

Correspondence:Jean Pierre Samedi Mucyo, Email: $\underline{\text { samedi.mucyo@gmail.com }}$

\begin{abstract}
High densities of large herbivores can have detrimental effects on plant biomass. Understanding the relationship between animal densities and plant distribution and abundance is essential for the conservation of endangered species and ecosystems. Mountain gorilla censuses conducted for different periods in the last three decades have revealed a steady increase of gorilla population in Virunga Massif whereby the recent number of gorillas has doubled compared to their number in the 1980s. It is unclear whether the continuous population growth of the herbivorous Virunga gorilla within an isolated forest 'island' has been affecting gorilla food plant biomass. This study investigated the effect of varying mountain gorilla densities on the biomass of the five key food plant species (Galium spp., Carduus nyassanus, Peucedanum linderi, Rubus spp., Laportea alatipes) that make up $>70 \%$ of the mountain gorilla diet. We used plant biomass data collected in a central part of the Virunga massif, commonly known as Karisoke sector from 2009 to 2011, and GPS records of gorilla groups ranging in the same area nine months prior biomass assessment. Gorilla densities were estimated using the Kernel Utilization Distribution (KDE) analysis (functions: 'kernelUD' and 'getvolumeUD') from the Adehabitat package in R software, which provides the probability density of gorilla occurrence at each coordinate $(x, y)$ of the study area. Analyses using GLMs suggest that gorilla densities (a proxy of previous gorilla utilization intensity) did neither affect the total biomass of key food plant species nor the biomass of each key food plant species $(\mathrm{p}>0.05)$. These results may indicate that current revisit rates of feeding sites by gorillas allow for complete plant regeneration, and no signs of overharvesting. Alternatively, feeding sites characterized by very high biomass may be preferred by gorillas and remain sites with the highest biomass even after being frequently used by gorillas. Findings also suggest that carrying capacity of the gorilla population in the study areas may not yet be reached if food is the driving constraint. However, monitoring of the relationship between gorilla densities and food plant biomass must continue while the Virunga population continues growing. Future studies also need to incorporate other sympatric large herbivores in the Virungas who share food plants with mountain gorillas.
\end{abstract}

Keywords: habitat use, gorilla density, plants biomass. 


\section{Introduction}

Investigating changes in the relationship between animals and their environment is one of the most relevant subjects in ecology (Calenge, 2006; Barton and Hanley, 2013). The environment determines the diet, movement patterns and in some cases, breeding cycles of a species, and is thus of great importance in wildlife management (Johnson, 1980; McNeilage, 1995). The population density of a species can be a fundamental driver of many ecological processes, including habitat selection (Beest et al., 2013). Therefore, monitoring of population density is important in the conservation of endangered species as it can be used to predict changes in species ecology. This knowledge can eventually help design mitigation measures to ease the impact of changes in population density on the available habitat of endangered species (Norris, 2004). Plants are producers in food webs and are therefore an essential ecosystem element that all animal communities are built on (Maron and Crone, 2006). Herbivores play a large role in shaping plant community compositions in their habitat by influencing species abundance and distribution through trampling and plant consumption (Watts, 1987; Plumptre, 1991; Maron and Crone, 2006; Barton and Hanley, 2013; Lefebvre and Gallet, 2017). However, the effects of herbivores on the abundance and distribution of plant species can be complex and exhibit extensive variability (Bigger and Marvier, 1998; Vesk and Mark, 2001; Maron and Crone, 2006). Effects can be detrimental on the fitness and productivity of plant species, which subsequently affects plant growth and distribution (Crawley, 1997; Bigger \& Marvier, 1998; Gomez, 2005; Tiffany, 2004). However, damage from herbivores can also result in higher plant productivity and biomass (Hawkes and Sullivan, 2001). On the other hand, some plants have developed mechanisms and traits towards a high tolerance to herbivory, often leading to negligible effects of herbivores on plant distribution and abundance (Strauss and Agrawal, 1999; Stowe et al., 2000).

Mountain gorillas are large herbivores that feed mainly on leaves, stems, and roots of different plant species (McNeilage, 2001). Censuses conducted previously on mountain gorilla in Virunga Massif have demonstrated a continuous increase in the gorilla number where the number nearly double from 250 individuals in 1981 to 480 individuals in 2010 (Gray et al., 2013). Moreover, the most recent census in 2016 revealed that the number of gorillas inhabiting Virunga massif has reached 604 individuals with 3.8 percent annual rate increase (Hickey et al., 2018). Census results have also shown an uneven distribution of gorilla groups throughout the Virunga habitat. Specifically, the southeastern-central region of the Virunga massif, known as the Karisoke sector, in the Volcanoes National Park (VNP) in Rwanda, has some of the highest observed gorilla density (Robbins et al., 2011; Gray et al., 2013).

In the Karisoke area, more than $80 \%$ of the gorilla's diet is composed of only six key plant species, namely Galium spp., thistles (Carduus nyassanus), wild celery (Peucedanum linderi), bamboo (Yushania alpina), blackberries (Rubus spp.) and nettles (Laportea alatipes) (Grueter et $a l ., 2013)$. These key gorilla food species are available all year-round, except for bamboo shoots which are only available for four months per year coinciding with the two rain seasons (Vedder, 1984; Watts, 1991). Grueter et al (2013) revealed changes in biomass in the top five most consumed gorilla food species in the Karisoke area; two of them (Galium spp. and Laportea alatipes) showed a decline in biomass, while the other three (Carduus nyassanus, Peucedanum linderi, and Rubus spp.) showed an increase in biomass as well as a shift in altitudinal distribution compared to that in 1989. However, whether these observed changes in biomass of 
gorilla key food species are linked to changes in gorilla ranging patterns, habitat use and population density in this south-eastern central forest area remain unknown.

Previous research suggests that when a herbivorous species consumes vegetation faster than the plants can regenerate, there can be considerable decreases in the availability of food resources for animals in the area (Watts, 1998b). Thus, differences in the usage of certain areas of the habitat in the light of growing gorilla densities can, therefore, result in over-harvesting of key gorilla food species. In addition, as the total population size increases, so does competition among gorilla groups for space in good quality areas. This may result in less competitive groups using poorer quality sites, and since access to high-quality food resources can affect female reproductive success, over-harvesting of food species by gorillas due to rapid increases in population growth may finally affect individual fitness (Norris, 2004; Robbins et al., 2007).

In this study we investigated the association between the local gorilla density (Proxy to gorilla visitation intensity) and the biomass of five key gorilla food species in the Karisoke research area in the Volcanoes National Park, Rwanda. Our goal is to evaluate if gorilla density affects key gorilla food plant biomass. We predicted that there will be a negative relationship between gorilla food biomass and previous gorilla density probability (i.e. low food biomass related to high population density was expected).

\section{Materials and Methods}

\subsection{Study site}

This research was undertaken in the Virunga Massif which stretches out between $1^{\circ}$ and $2^{\circ}$ of latitude South and $29^{\circ}$ to $30^{\circ}$ of longitude East at the borders of Democratic Republic of Congo (DRC), Uganda and Rwanda. Virunga Massif comprises three adjacent national parks: Virunga National Park (DRC), Mgahinga Gorilla National Park (Uganda) and Volcanoes National Park (Rwanda). The Virunga massif is an afromontane forest and lies on six extinct volcanoes respectively from East to West Muhabura (4,127 m), Gahinga (3,474 m), Sabyinyo (3,634 m), Bisoke $(3,711 \mathrm{~m})$, Karisimbi $(4,507 \mathrm{~m})$ and Mikeno $(4,380 \mathrm{~m})$ and range from an altitude of 2300 to 4,507 meters above sea level covering of approximately $450 \mathrm{~km}^{2}$ (Weber, 1987). Nine vegetation zones can be distinguished from the lowest to the highest altitude in the Virunga Massif based on the dominant plant species in each altitudinal zone (McNeilage, 1995; Figure 1). This area is rich in biodiversity with 61 animal and 124 plant species which are endemic (Owiounji et al, 2005). Along with Bwindi Impenetrable National Park (Uganda), it is the last remaining habitat of the endangered mountain gorillas. According to Plumptre et al (2003), Virunga Massif has a total list of 86 species of mammals out of which 34 are large mammals. The larger mammals include six herbivorous larger mammals which are mountain gorilla (Gorilla beringei beringei), buffalo (Syncerus caffer), bushbuck (Tragelaphus scriptus), blackfronted duiker (Cephalophus nigrifrons) and elephant (Loxondata africana) (Owiounji et al, 2005). The area is also a habitat to endangered golden monkey (Cercophithecus mitis kandti) which has a diet that overlapping with one of the gorillas. 


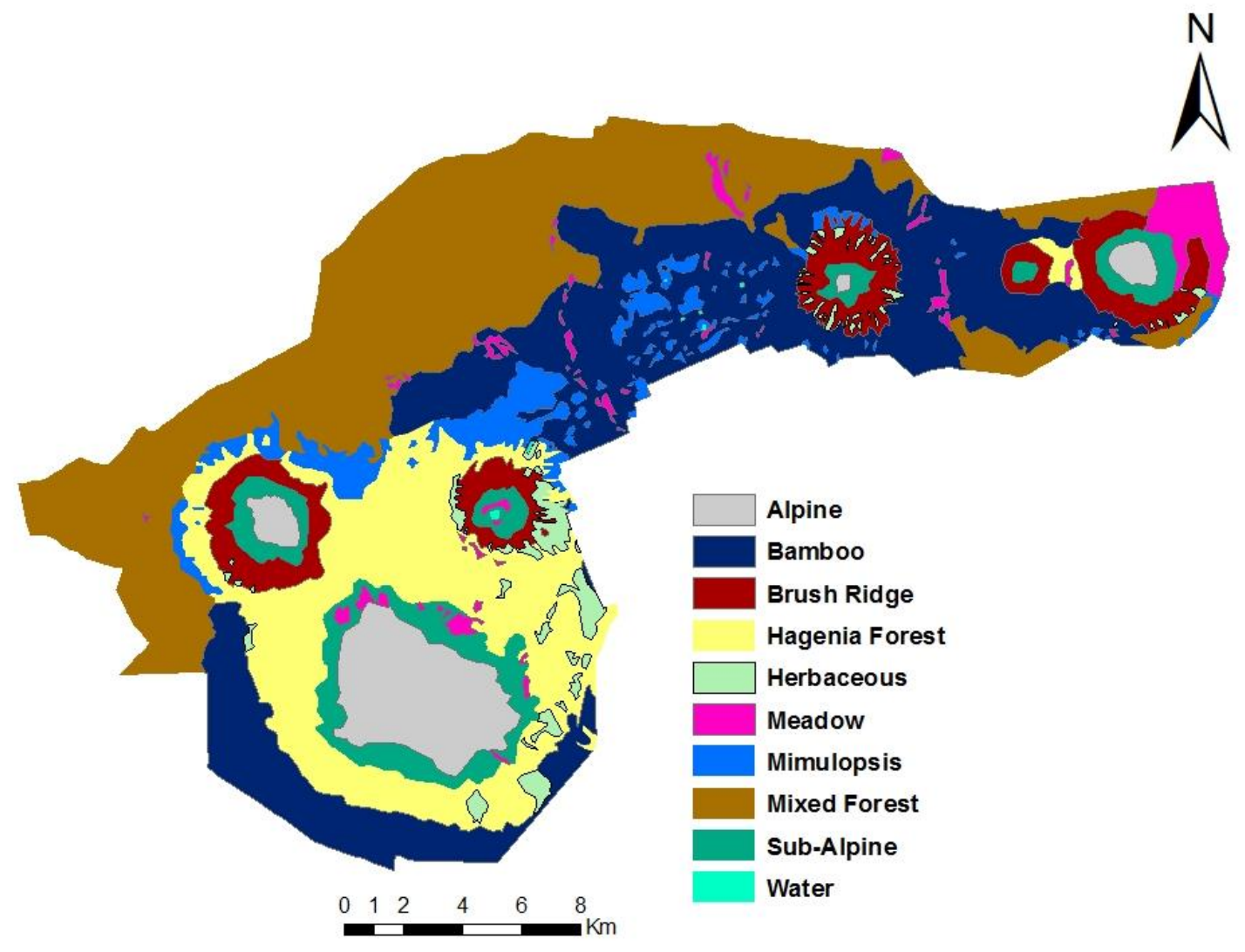

Figure 1.Vegetation types distribution in Virunga Massif

\subsection{Study Gorilla Groups}

The current research was conducted on habituated gorilla groups that were ranging in the center part of the park of the Volcanoes National Park (VNP) in an area commonly called Karisoke which situated between Karisimbi and Bisoke Volcanoes (Fig. 2). During the study period (from 2009 to 2011), Karisoke research gorilla population mean size was 123 gorillas distributed in 9 social groups (Fig.2;Table1.)

Table 1. Summary of the study groups mean composition from 2009 to 2011.

\begin{tabular}{|l|c|l|}
\hline Group Name & $\begin{array}{c}\text { Mean group } \\
\text { size }\end{array}$ & \multicolumn{1}{|c|}{ Mean Age sex class composition* } \\
\hline Pablo (PAB) & 46 & $\begin{array}{l}5 \mathrm{SB}, 14 \mathrm{AF}, 7 \mathrm{BB}, 6 \mathrm{SA}, 4 \mathrm{JUV}, \\
10 \mathrm{INF}\end{array}$ \\
\hline Kuryama (KUY) & 14 & $3 \mathrm{SB}, 3 \mathrm{AF}, 2 \mathrm{BB}, 4 \mathrm{JUV}, 2 \mathrm{INF}$ \\
\hline Bwenge (BWE) & 11 & $1 \mathrm{SB}, 5 \mathrm{AF}, 2 \mathrm{JUV}, 3 \mathrm{INF}$ \\
\hline Isabukuru (ISA) & 12 & $2 \mathrm{SB}, 5 \mathrm{AF}, 1 \mathrm{JUV}, 4 \mathrm{INF}$ \\
\hline
\end{tabular}




\begin{tabular}{|l|c|l|}
\hline Ntambara (NTA) & 11 & 3SB, 5AF, 1, JUV, 2INF \\
\hline Titus (TIT) & 7 & 2SB, 2BB, 1 SA, 2AF \\
\hline Ugenda (UGE) & 10 & 2SB, 4AF, 3JUV, 1INF \\
\hline Urugamba (URU) & 6 & 1SB, 2AF, 1 SA, 1JUV, 1 INF \\
\hline Inshuti (INS) & 6 & 1SB, 3AF, 2INF \\
\hline
\end{tabular}

${ }^{*} \mathrm{SB}=$ Silverback $(\geq 12$ years male); $\mathrm{BB}=$ Blackback $(8-12$ years male); $\mathrm{ADF}=$ Adult female ( $\geq 8$ years female); $\mathrm{SA}=$ Subadult $(6-8$ years); JUV = Juvenile (3.5-6 years); INF = Infant (0-3.5 years).

\subsection{Plant biomass data}

Plant biomass data of five key gorilla food species (Galium spp., Carduus nyassanus, Peucedanum linderi, Rubus spp, and Laportea alatipes) and their corresponding GPS coordinates were obtained from a study that was carried out by Grueter between 2009 to 2011 in the southern central part of VNP commonly known as Karisoke area (Grueter et al., 2013). Grueter et al. (2013) sampled vegetation in two phases. The first phase lasted from September 2009 to May 2010 and covered an area of approximately $6 \mathrm{~km}^{2}$, while the second phase lasted from June 2010 to March 2011 and covered approximately $25 \mathrm{~km}^{2}$ (for more details see Grueter et al. 2013; Figure 2). A stratified random sampling method was used, and the study area was divided into a grid with cells of approximately $100 \mathrm{~m}$ and $250 \mathrm{~m}$ length in the first phase and the second phase, respectively. A nested circular plot was randomly located within each cell (Plumptre, 1991; Grueter et al., 2013). Different plot sizes were used for assessing biomass of different plant types: $1 \mathrm{~m}^{2}(\mathrm{r}=0.56 \mathrm{~m})$ for tall herbs and vines, $5 \mathrm{~m}^{2}(\mathrm{r}=1.26 \mathrm{~m})$ for shrubs, and $10 \mathrm{~m}^{2}(\mathrm{r}=1.79 \mathrm{~m})$ for trees (Grueter et al., 2013). A total of 969 plots were established in both phases (Grueter et al., 2013).

Dry biomass of the five key plant species was obtained using different methods. For the tall herbs (Carduus nyassanus, Peucedanum linderi, and Laportea alatipes), their biomass was estimated based on the assumption that one measurable plant trait correlates with the total biomass of the plant individual (Whittaker, 1965). Thus, the measurements of stem and leaf length of these tall herbs were recorded, then their length measurements were entered into existing phytometric regression equations developed by Plumptre which relate stem height and leaf length to the dry biomass of the plant (Plumptre, 1991). For Galium sp which is a vine and grows in tangles on other plants, their biomass was obtained by harvesting all the Galium $s p$ found in the plot and then dried them and measured on a high precision balance at Karisoke Research Center laboratory facilities. For Rubus sp., which is a shrub and which the length vegetative parts are not easily measured, 50 leaves (including petioles) were collected and obtained the average weight of the Rubus sp leaves, which we subsequently used for biomass estimates by multiplying with the number of the leaves counted on each Rubus species found in the plot. 


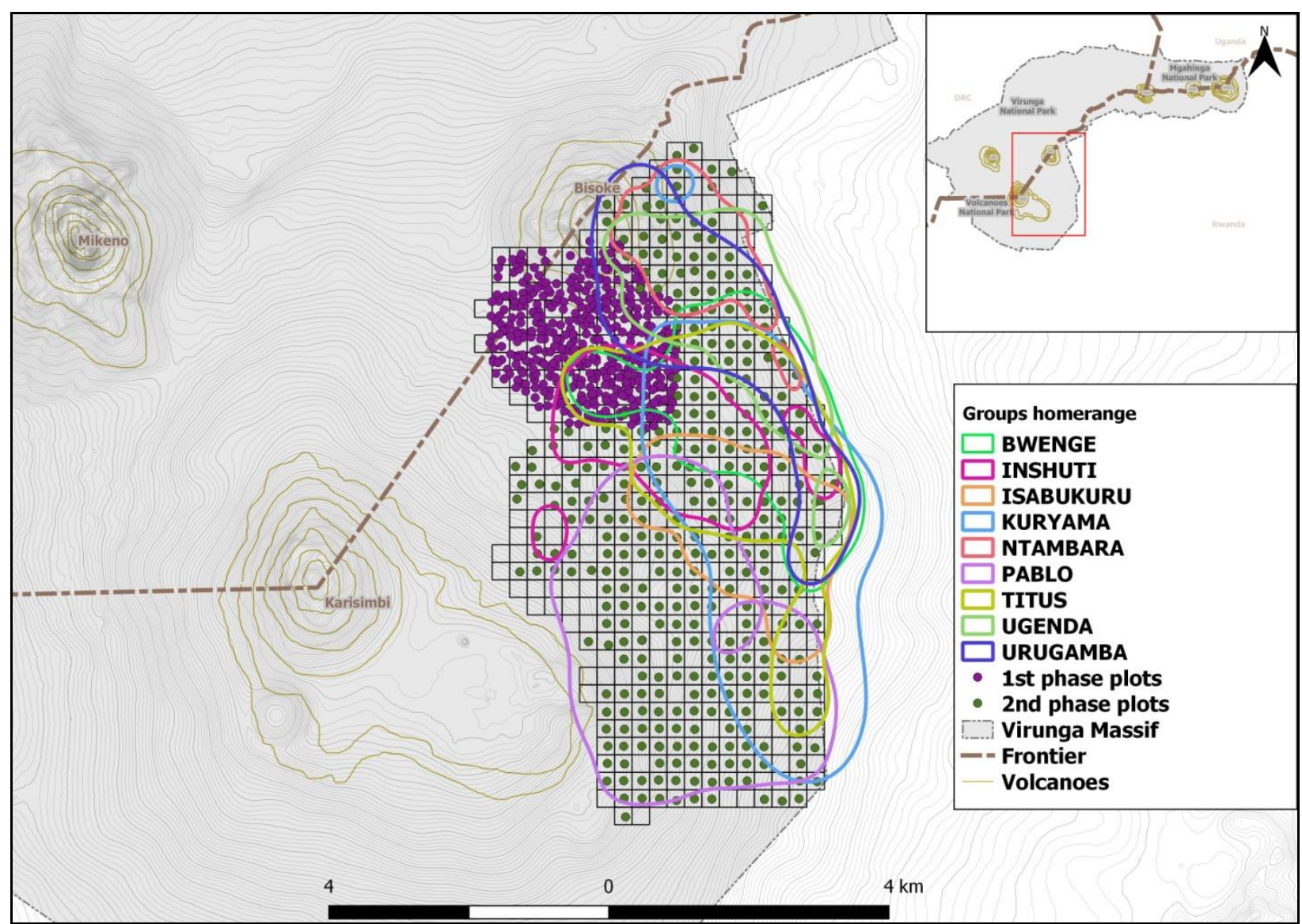

Figure 2. Karisoke research area showing plant biomass plots assessed in two phases and gorilla groups home ranges from January 2009 to March 2011.

\subsection{Gorilla location data}

GPS coordinates were recorded using handheld GARMIN GPS devices twice a day in each monitored group. The first GPS point corresponded to the location of the night nest site where the group spent the previous night, and the second GPS point corresponded to the location of the group at noon. The GPS points were recorded in UTM projection, which has coordinate-units of 1 meter. We used GPS coordinates collected in nine consecutive months prior to the date of biomass sampling for each sampled plot. The criteria of nine months prior to the plant biomass assessment was chosen because a full regeneration of herbaceous gorilla food typically requires six to eight months after being fed on and/or trampled (Plumptre, 1993; Watts, 1998). In addition, to investigate whether gorilla densities have a shorter or longer term effect on the biomass of consumed key food plants, we also calculated gorilla densities derived from GPS data of one month and five years prior the biomass assessment in each plot.

\section{Data Analysis}

Gorilla densities were calculated using locations of gorilla groups that were ranging in the study area and monitored by KRC. We controlled for differences in the amount of food consumed and 
trampling at feeding sites related to group size by replicating each GPS location by the number of weaned individuals in a group in the data set (i.e. over the age of 3 years, Caillaud et al., 2014). The dataset analyzed here includes a total of 13,330 GPS points. These GPS coordinates were then used to calculate the intensity of habitat use by gorillas using the Kernel Utilization Distribution (KDE) analysis (Worton, 1989). This method generates utilization distributions, which represent animal's relative use of space (Van Winkle, 1975). KDE is a weighted probability function which is put over each observations data point and then aggregating them to yield the overall density (Worton, 1989). In this way kernel function estimate high density in the place that has a high concentration of data points than in the place that has few points and it insures that the contribution of each point to the density of an area is inversely proportion to its distance to that area (Worton, 1989). To have a robust estimate of utilization density we need to have a good value for one of the important parameter in Kernel Density Estimation method which is known as the smoothing (or bandwidth) parameter commonly written as $h$ as the small value of $h$ could lead to underestimate of utilization density and large value of $h$ could lead to overestimate of utilization density (Worton, 1989; Kie et al., 2010). There are many methods to estimates the bandwidth parameter (Worton, 1989) but the most commonly used method to estimate the bandwidth parameter is the least-square cross validation method, however the least square cross validation method has been demonstrated to be sensitive to data size and can lead to an underestimation of the utilization density when the sample size is large (Kie et al., 2010). In this study we choose to use a fixed bandwidth parameter of $200 \mathrm{~m}$ as in previous studies of mountain gorillas this fixed bandwidth of $200 \mathrm{~m}$ showed to produce utilization density which is robust to data size change (Caillaud, et al., 2014; Seiler et al., 2017). All Kernel utilization density calculations were performed using software 3.4.3. (R. Core Team, 2017) and package Adehabitat HR (Calenge, 2006), which provides the density based probability of animal occurrence (in our case gorilla groups) at each coordinate of the study area (Calenge, 2015).

After calculating KDE, the 'raster' function in the raster library (Hijmans, 2017) in R software was used to convert the KDE output into a raster image, where the values in each pixel of the image corresponding to the probability of a gorilla occurring in that particular pixel, which is directly related to the density of gorillas (higher probability of finding a gorilla = higher density). Finally, the raster image was overlaid with the GPS locations of biomass grids and by using the 'extract' function in R, we estimated the density values corresponding to the coordinates of each grid cell in which plant biomass was sampled.

To assess whether the change in biomass of (1) each of the five key food species and (2) the total key food plant biomass was correlated to gorilla density probability, General Linear models (GLMs) was used, which included food biomass as the dependent variable and gorilla density as the predictor variable. The log-transformation of food biomass and gorilla density data was done before analysis to normalize the data. The plant biomasses from both phases were analyzed together, and a p-value threshold of 0.05 was used to detect statistical significance. 


\section{Results}

\subsection{Distribution of key gorilla food plant biomass and gorillas densities}

There was a wide variation in the biomass of gorilla key food within the study area ranging between $0.2 \mathrm{~g} / \mathrm{m}^{2}$ to $755.6 \mathrm{~g} / \mathrm{m}^{2}$ in the plots sampled with a mean $( \pm \mathrm{SD})$ biomass of 117.5 $( \pm 117.3) \mathrm{g} / \mathrm{m}^{2}$ (Figure 3). Similarly, habitat use by gorillas was highly variable, with the gorilla density probability ranging between $0 \%$ and $99.97 \%$ and a mean $( \pm$ SD) of $20.68( \pm 26.53) \%$ (Figure 4). 


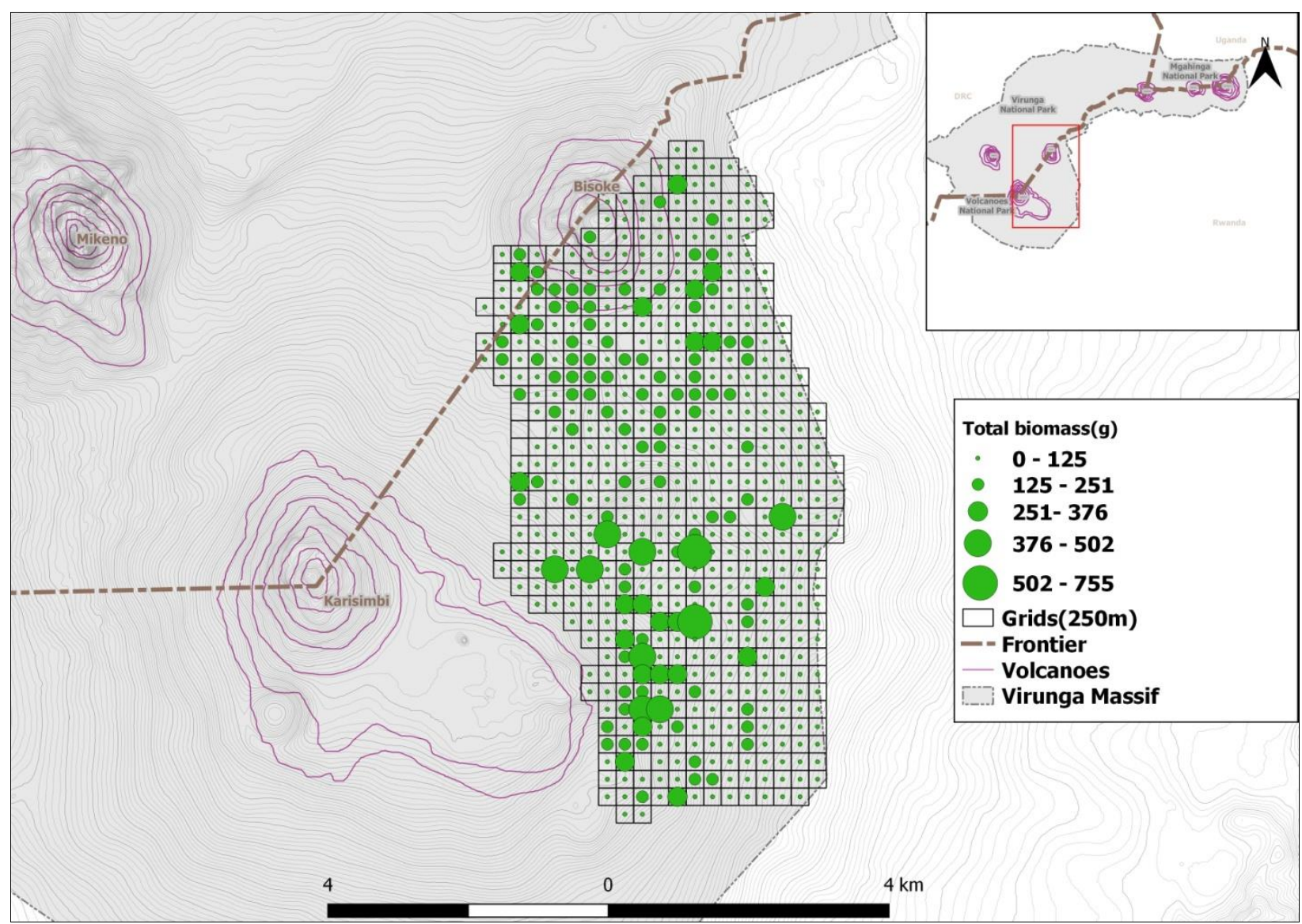

Figure 3. Total biomass (in grams) of the five key gorilla food species in each study plot located in the Karisoke study area (from September 2009 to March 2011). 


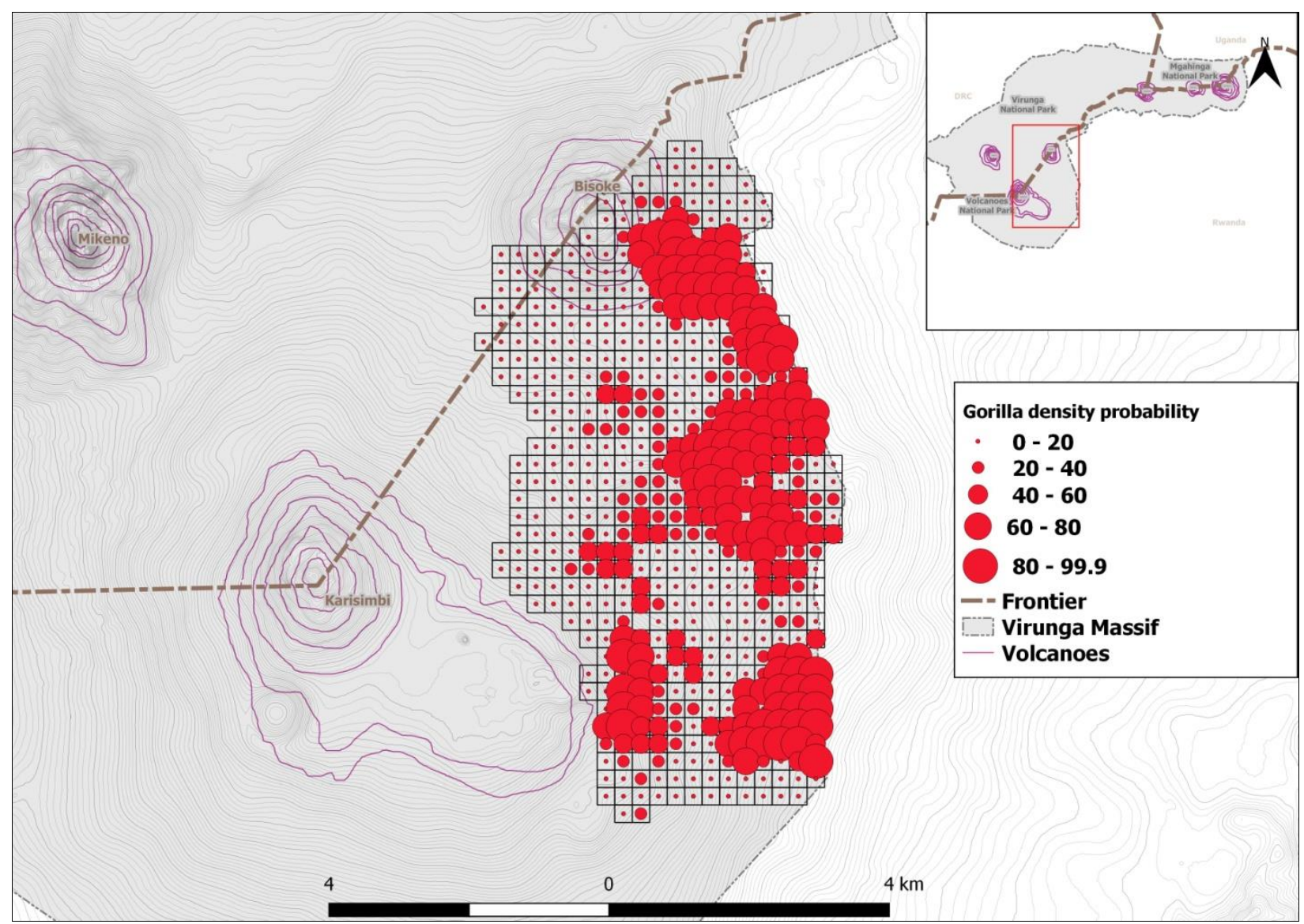

Figure 4. Variation in gorilla density probability (\%) in every grid of $250 \mathrm{~m}$ of the side corresponding to where the plant biomass was collected in the study area (from September 2009 to March 2011).

\subsection{Relationship between key gorilla food biomass and gorilla density probability}

A significant relationship was not found neither between the gorilla density probability and the biomass of any key food species nor between gorilla density probability and the total biomass of these key food species (Table 2 \& Fig. 5).

\begin{tabular}{l|c|c|c|c|}
\hline Species name & $\begin{array}{l}\text { Number } \\
\text { of plots }\end{array}$ & $\begin{array}{l}\text { Degree of } \\
\text { freedom }\end{array}$ & F-statistic & P-Value \\
\hline Galium sp & 246 & $(1,245)$ & 1.44 & 0.231 \\
\hline $\begin{array}{l}\text { Carduus } \\
\text { nyassanus }\end{array}$ & 216 & $(1,215)$ & 0.02 & 0.878 \\
\hline $\begin{array}{l}\text { Pceudanum } \\
\text { linderi }\end{array}$ & 95 & $(1,94)$ & 1.33 & 0.251 \\
\hline Laportea & 345 & $(1,344)$ & 0.52 & 0.474 \\
\hline
\end{tabular}




\begin{tabular}{l|c|c|c|c|}
\hline alatipes & & & & \\
\hline Rubus $s p$ & 262 & $(1,261)$ & 0.02 & 0.886 \\
\hline $\begin{array}{l}\text { All species } \\
\text { (Total) }\end{array}$ & 732 & $(1,731)$ & 1.66 & 0.197 \\
\hline
\end{tabular}

Table 2. Statistical output of model investigating the relationship between key food plant biomass and gorilla density probability.

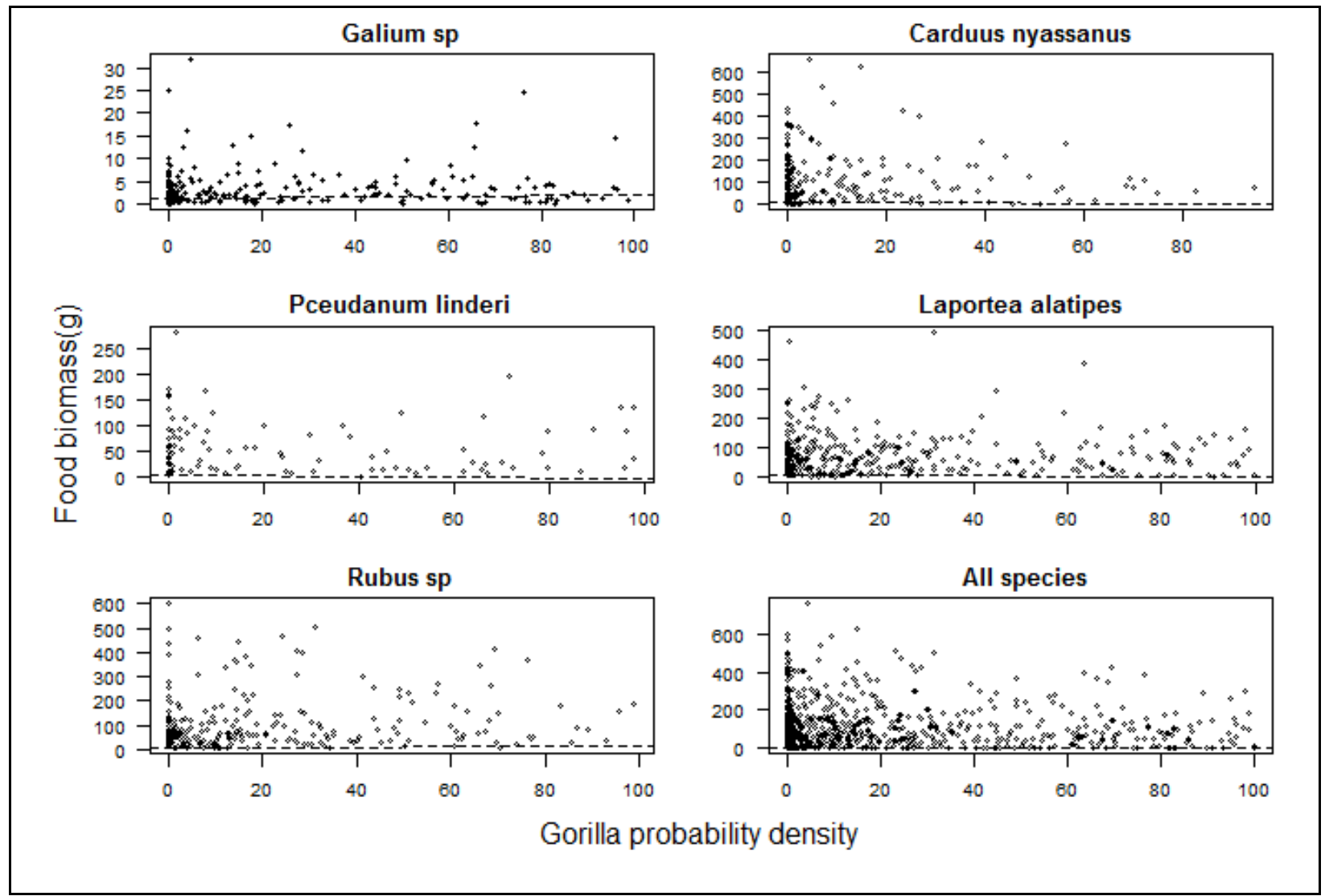

Figure 5. Scatter plots showing the relationship between key food plant biomass (in grams) and gorilla density probability $(\%)$.

In terms of the short-term effect of changes in gorilla density (1-month gorilla density probability before biomass assessment) and long-term effect of changes in gorilla density (5 years gorilla density probability before biomass assessment) on plant biomass, we also found no correlation between the gorilla density probability and the biomass of each single key food species and the total biomass, $\mathrm{P}>0.05$. We also compared the mean biomass of key species in grid cells where we have high density probability of gorilla (over than 70\%) and the mean biomass of the grid where we have lower density probability of gorilla (less than 1\%) and using t-test we found that the means were not statistically significant neither for each key species nor for total biomass of these key food species, P>0.05 (Figure 6). 


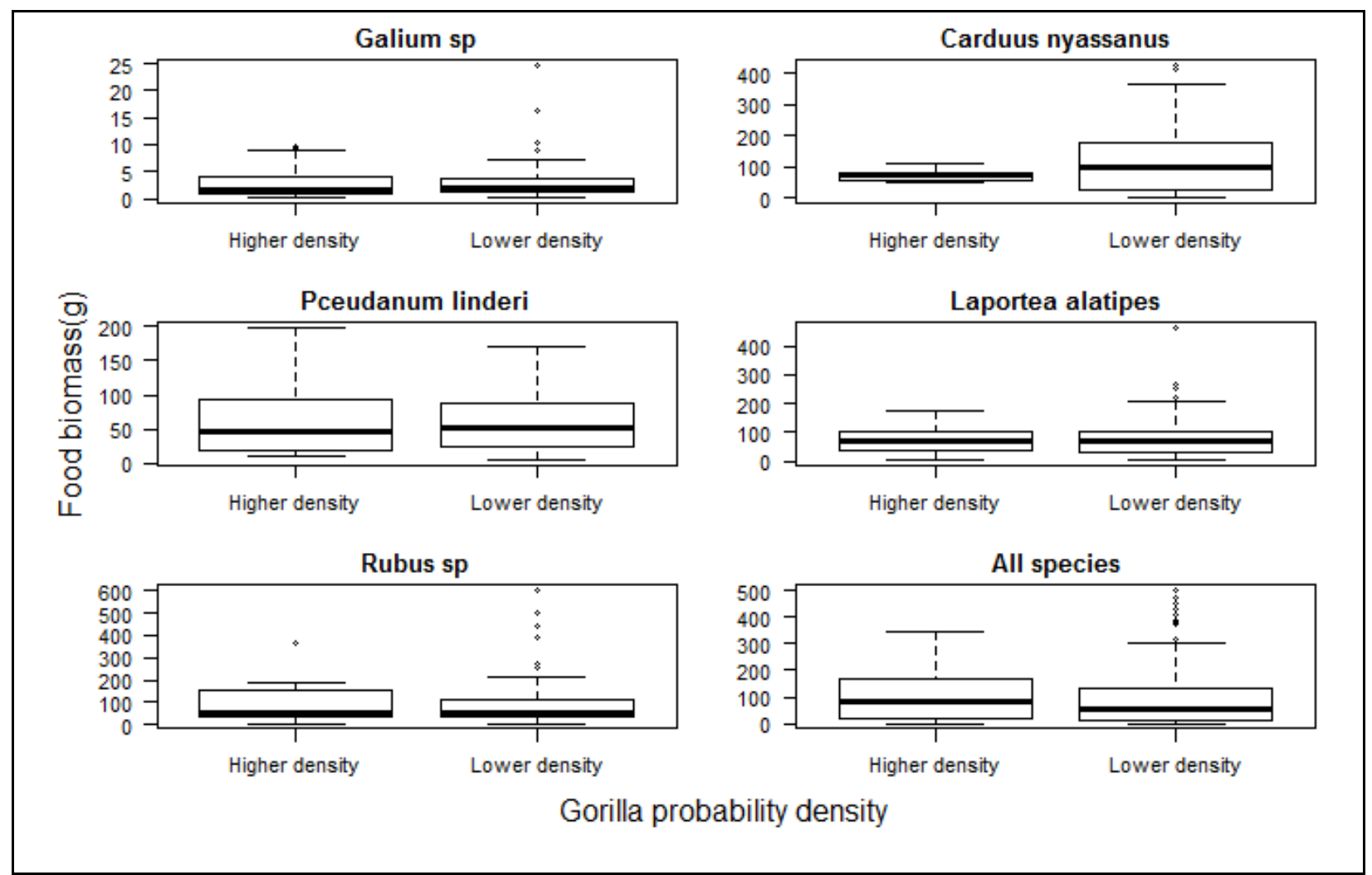

Figure 6. Box-plots plots showing comparisons of biomass in areas of higher and lower gorilla density.

\subsection{Discussion}

The goal of this study was to investigate if an increasing number of gorillas has impacted the availability of their key food species. The findings suggest that the biomass of the five most consumed gorilla food species in the Karisoke research area cannot only be explained by gorilla habitat use (Fig. 6). Areas characterized by a higher probability of being visited by gorillas did not show lower food availability as expected, and thus there were no signs of overharvesting by the end of this study period in 2010. These results suggest that the habitat in the study area still had a high gorilla food resource availability and therefore can still sustain the growing population of mountain gorillas if food is limiting factor. This is in line with other studies that have suggested that the Virunga massif can sustain a high number of herbivores due to its high biomass of herbaceous vegetation (Plumptre, 1991; McNeilage, 1995; Robbins et al., 2007). Also having no statistical differences in means of biomass in areas with high probability density and in lower probability density of gorillas confirm that herbaceous key gorilla food species are generally abundant and evenly distributed in this study area (Watts, 1984; McNeilage, 2001). While food abundance remains high in this area, mountain gorilla competition for food stays low (Watts, 1998a; Robbins et al., 2007), and it could explain why areas with high gorilla density do not show decline in the food biomass as gorillas while feeding, they do not exhaust food recourses in used areas (Fossey \& Harcourt, 1977), and adjust their revisits patterns to the 
previous use (Watts, 1998b). In addition, mountain gorillas typically only partially defoliate a plant (Fossey \& Harcourt, 1977; Watts, 1987), which can allow a faster vegetative regeneration. Moreover, the lack of effect of gorilla density on food plant biomass may be related to the potential positive effect of damage by gorillas, where trampling of the plants can stimulate the primary productivity of food species (Watts, 1987), which can outweigh the negative effect caused by feeding.

A population density of gorillas is positively correlated with food availability, thus gorilla density is highest where particular herbaceous, staple foods are found in high abundance (Bermejo, 1999; Rogers et al, 2004). In addition, previous studies showed that mountain gorillas forage in areas where food resources are abundant and of high quality (Vedder, 1984; Watts, 1991; Watts, 1998). Similarly, a recent study on mountain gorillas in Bwindi showed that high abundance of herbaceous gorilla food is linked to smaller gorilla home range sizes because gorilla can stay longer in the area with high food availability (Seiler et al., 2018). Therefore, findings from this study may also suggest that areas preferred by the study groups had such high food availability that despite frequent gorilla visitation rates, food availability remained relatively high compared to other areas, and thus masks effects investigated in this study.

Moreover, ranging patterns of gorillas are not only driven by food availability; social factors, such as the proximity to neighboring groups (Fossey \& Harcourt, 1977; Watts, 1991), and anthropogenic disturbances play an important role (Watts, 1991; Gray et al., 2013; Caillaud et al., 2014; Seiler et al., 2018). Therefore, future studies should integrate the social aspects such as groups encounters frequency, and human disturbances (snares) distribution in the analysis for a better understanding of gorilla space use patterns.

\section{Conclusion and Recommendations}

This study investigated the effect of varying mountain gorilla densities on the biomass of the five key food plant species. Results indicated that gorilla densities did neither affect the total biomass of key food plant species nor the biomass of each key food plant species. Results demonstrate the complex nature of plant-herbivore relationships and the need to consider other potential factors that affect herbivores' ranging patterns and plant biomass, distribution, and regeneration in future investigations, such as social interactions between gorilla groups, habitat canopy cover, slope, altitude, soil $\mathrm{pH}$, water retention, temperature, and ranging patterns of other herbivores that share gorilla diet. I recommend the extension of this study to the whole VNP using marked plots to regularly monitor effects of gorilla visits, human influences, climate, a wide range of habitat conditions, and other herbivores on gorilla food plant biomass across the park. The fact that population growth was not homogeneous throughout the park, thus it is important to include different forest areas for better understanding the relationship between gorilla density and plant biomass. Our results also showed that the gorilla food plants distribution is clumped (i.e. not following a regular pattern) then biomass resulting from only one plot may not be representative of a $250 \mathrm{~m}^{2}$ and $100 \mathrm{~m}^{2}$ forest quadrant. We, therefore, propose to establish at least five plots in each quadrant; one at the center of the quadrant and one in each corner of the quadrant so that we can capture the variation on topography, aspect, apparent floristic differences and other physical features of the quadrant. Future studies, also needs to record the cause of the plants damage such as trampling, partial consumption or complete consumption, so that we can understand how different types of plant damage by herbivores are affecting the growth of the plant. As the 
population of gorilla continues to increase steadily, potential density effect may become severe and more obvious in coming decades, this effect alongside with climate change can change the plant- gorilla dynamics and requires continuous monitoring for better management of gorilla and their habitat.

\section{Acknowledgment}

We would like to thank Rwanda Development Board for granting the permit to collect the data used in this research. We thank the Dian Fossey Gorilla Fund International for providing financial support and gorilla ranging data to carry out this research. Equally we are very grateful to Cyril C. Grueter for providing us the plant biomass data. We also indebted to Mrs Caitlin for providing the financial support in this study. 


\section{References}

Aldefer, R. G. and Eagles, C. F. (1976). The effect of partial defoliation on the growth and photosynthetic efficiency of bean leaves. Botanical gazette, 137(4), pp. 351-355.

Auslander, M., Nevo, E. and Inbar, M. (2003). The effects of slope orientation on plant growth , developmental instability and susceptibility to herbivores. Journal of Arid Environments, 55, pp. 405-416. doi: 10.1016/S0140-1963(02)00281-1.

Barton, E. K. and Hanley, E. M. (2013). Seedling - herbivore interactions : insights into plant defence and regeneration patterns. Annals of Botany, 112, pp. 643-650. doi: 10.1093/aob/mct139.

Beest,V. F. M., Uzal, A., Wal, V. E., Laforge, P. M., Contasti, L. A., Colville, D., McLoughlin, D. P. (2013). Increasing density leads to generalization in both coarse-grained habitat selection and fine-grained resource selection in a large mammal. Journal of Animal Ecology, 83(1), pp. 110. doi: 10.1111/1365-2656.12115.

Bermejo, M. (1999). Status and Conservation of primates in Odzala National Park, Republic of the Congo. Oryx, 33, pp. 323-321.

Bigger, D. S. and Marvier, M. A. (1998). How Different Would a World Without Herbivory Be ?: A Search for Generality in Ecology. Integrative Biology, pp. 60-67.

Caillaud, D., Ndagijimana, F., Giarrusso, A. J., Vecelio, V., Stoinski, S. T. (2014). Mountain gorilla ranging patterns: Influence of group size and group dynamics. American Journal of Primatology, 76(8), pp. 730-746. doi: 10.1002/ajp.22265.

Caldeira, M. C., Ibaneze, I., Noguiera, C., Bughalo, N. M., Lecomte, X., Moreira, A., Pereira, S. J. (2014). Direct and indirect effects of tree canopy facilitation in the recruitment of Mediterranean oaks. Journal of Applied Ecology, 51, pp. 349-358. doi: 10.1111/13652664.12189.

Calenge, C. (2006). The package adehabitat for the R software: a tool for the analysis of space and habitat use by animals. Ecological Modelling, 197, pp. 516-519. doi: 10.1016/j.ecolmodel.2006.03.017.

Calenge, C. (2015). Home Range Estimation in R : the adehabitatHR Package.

Chapman, C. A., Chapman, L. J. and Rode, K. D. (2003). Variation in the Nutritional Value of Primate Foods: Among Trees, Time Periods, and Areas Variation in the Nutritional Value of Primate Foods : Among Trees, Time Periods, and Areas. International Journal of Primatology, 24(2). doi: 10.1023/A.

Cierjacks, A., Ruhr, N. K., Wesche, K., Hensen, I (2008). Effects of altitude and livestock on the regeneration of two tree line forming Polylepis species in Ecuador. Plant Ecology, 194, pp. 207- 
221. doi: $10.1007 / \mathrm{s} 11258-007-9285-\mathrm{x}$.

Doran-Sheehy, M. D., Greer, D., Mongo, P., Schwindt, D. (2004). Impact of ecological and social factors on ranging in western gorillas. American Journal of Primatology 64:207-222.

Fossey, D., and Harcourt, A. H. (1977). Feeding ecology of free ranging mountain gorillas (Gorilla gorilla beringei). In: Clutton-Brock, T. H (ed) Primate ecology: studies of feeding and ranging behavior in lemurs, monkeys and apes. Academic Press, London, pp 539-556.

Ganas, J., Robbins, M. M., Nkurunungi, J. B., Kaplin, B. A., McNeilage, A. (2004). Dietary Variability of mountain gorillas in Bwindi impenetrable National Park, Uganda. Int J. Primatol. 25:1043-1072.

Ganas J., and Robbins, M. M. (2005). Ranging behavior of the mountain gorillas (Gorilla beringei beringei) in Bwindi Impenetrable National Park, Uganda: a test of the ecological constraints model. Behavioral Ecology and Sociobiology 58:277-288.

Gomez, J. M. (2005). Long-Term Effects of Ungulates on Performance , Abundance, and Spatial Distribution of Two Montane Herbs. Ecological Monographs, 75(2), pp. 231-258.

Grant, J. W. A., Chapman, C. A., and Richardson, K. S. (1992). Defended versus undefended home range size of carnivores, ungulates and primates. Behavioral Ecology and Sociobiology, $31(3), 149-161$.

Gray, M., Roy, J., Vigilant, L., Fawcett, K., Basabose, A., Cranfield, M., ...Robbins, M. M. (2013). Genetic census reveals increased but uneven growth of a critically endangered mountain gorilla population. Biological Conservation, 158, pp. 230-238. doi: 10.1016/j.biocon.2012.09.018.

Grueter, C. C., Ndamiyabo, F., Plumptre, J. A., Abavandimwe, D., Mundry, R., Fawcett, A. K., Robbins, M. M. (2013). Long-Term Temporal and Spatial Dynamics of Food Availability for Endangered Mountain Gorillas in Volcanoes National Park, Rwanda. American Journal of Primatology, 280(October 2012), pp. 267-280. doi: 10.1002/ajp.22102.

Guo, Y., Yu, Q., Feng, X., Ziel, Z., Liu, X. (2015). Effects of partial defoliation on the growth , ion relations and photosynthesis of Lycium chinense Mill . under salt stress. Archives of Biological Science Belgrade, 67(4), pp. 1185-1194. doi: 10.2298/ABS150211094G.

Hawkes, C. V and Sullivan, J. J. (2001). The Impact of Herbivory on Plants in Different Resource Conditions : A Meta-Analysis. Ecology, 82(7), pp. 2045-2058.

Hickey, J.R., Basabose, A., Gilardi, K.V., Greer, D., Nampindo, S., Robbins, M.M., Stoinski, T.S. (2018). Gorilla beringei ssp. beringei. The IUCN Red List of Threatened Species 2018:e.T39999A17989719. http://dx.doi.org/10.2305/IUCN.UK.2018-

2.RLTS.T39999A17989719.en. Downloaded on 19 February 2019.

Hijmans, R. J. (2017). raster: Geographic Data Analysis and Modeling. R package version 2.6-7. https://CRAN.R-project.org/package=raster

Johnson, H. D. (1980). The Comparison of Usage and Availability Measurements for Evaluating Resource Preference. Ecology, 61. 
Khan, N. A. and Lone, P. M. (2005). Effects of early and late season defoliation on photosynthesis, growth and yeild of mustard (Brassica juncea L.). Braz. J. Plant Physiol, 17(1), pp. 181-186.

Kie JG, Matthiopoulos J, Fieberg J, et al. 2010. The home-range concept: are traditional estimators still relevant with modern telemetry technology? Philosophical Transactions of the Royal Society B 365:2221-2231.

Lefebvre, T. and Gallet, C. (2017). Impacts des grands herbivores sur la végétation des prairies et conséquences sur la décomposition de la litière. INRA Prod. Anim, 30(5), pp. 455-464.

Maron, J. L. and Crone, E. (2006). Herbivory: effects on plant abundance, distribution and population growth. Proceedings of the Royal Society B, 273, pp. 2575-2584. doi: 10.1098/rspb.2006.3587.

McNeilage, A. (2001). Diet and Habitat Use of two mountain gorilla groups in contrasting habitats in the Virungas. In: Martha M. Robbins, Pascale Sicotte, K. J. S. (ed.) Mountain Gorillas Three Decades of Research at Karisoke. Cambridge University Press, pp. 265-292.

McNeilage, A. J. (1995). Mountain Gorillas In The Virunga Volcanoes: Ecology and Carrying Capacity. University of Bristol. PhD Thesis.

Nishar, A. Bader, K. F. M., O'Gorman, J. E., Deng, J., Breen, B., Leuzinger, S. (2017). Temperature Effects on Biomass and Regeneration of Vegetation in a Geothermal Area. Frontiers in Plant Science, 8(249), pp. 1-11. doi: 10.3389/fpls.2017.00249.

Norris, K. (2004). Managing threatened species : the ecological toolbox , evolutionary theory and declining-population paradigm. Journal of Applied Ecology, 41, pp. 413-426.

Olff, H. and Ritchie, E. M. (1998). Effects of herbivores on grassland plant diversity. Trends in Ecology and Evolution, 13(7). doi: 10.1016/S0169-5347(98)01364-0.

Olofsson, J., Hulme, E. P., Okasaneni, L., Suominen, O. (2005). Effects of mammalian herbivores on revegetation of disturbed areas in the forest-tundra ecotone in northern Fennoscandia. Landscape Ecology, 20, pp. 351-359. doi: 10.1007/s10980-005-3166-2.

Owiunji, I., Nkuutu, D., Kujirakwinja, D., Liengola, I., Plumptre, J. A., Nsanzurwimo, A.,... McNeilage, A. (2005). The Biodiversity of the Virunga Volcanoes. Biological Survey of Virunga Volcanoes. Kigali, Rwanda: Wildlife Conservation Society.

Plumptre, J. A. (1991). Plant-Herbivore dynamics in the Birungas. PhD Thesis.

Plumptre, J. A. (1993). The effects of trampling damage by herbivores on the vegetation of the Parc National des Volcans, Rwanda. African Journal of Ecology, 32, pp. 115-129. 
Plumptre, A.J., Behangana, M., Davenport, T.R.B., Kahindo, C., Kityo, R., Ndomba, E., .... Eilu, G. (2003). The Biodiversity of the Albertine Rift. Albertine Rift Technical Reports No. 3, pp105.

R Core Team (2017). R: A language and environment for statistical computing. R Foundation for Statistical Computing, Vienna, Austria. URL https://www.R-project.org/.

Robbins, M. M., Robbins, A. M., Gerald-Steklis, N., Steklis, D. H. (2007). Socioecological influences on the reproductive success of female mountain gorillas ( Gorilla beringei beringei ). Behav Ecol Sociobiol, 61, pp. 919-931. doi: 10.1007/s00265-006-0321-y.

Robbins, M. M. Gray, M., Fawcett, K. A., Nutter, F. B., Uwingeli, P., Mburanumwe, I., ... Robbins, A. M. (2011). Extreme Conservation Leads to Recovery of the Virunga Mountain Gorillas. PLoS ONE, 6(6). doi: 10.1371/journal.pone.0019788.

Rogers, M. E., Abernethy, K., Bermejo, M., Cipolletta, C., Doran, D., Mcfarland, K., ....Tutin, C. E. G. (2004). Western Gorilla diet: a synthesis from six sites. AM. J. primatol, 64, pp. 173-192.

Seiler, N., Boesch, C., Mundry, R., Stephens, C., \& Robbins, M. M. (2017). Space partitioning in wild, non-territorial mountain gorillas: The impact of food and neighbours. Royal Society Open Science, 4(11), 170720.https://doi.org/10.1098/rsos.170720

Seiler, N., Boesch, C., Stephens, C., Ortmann, S., Mundry, R., Robbins, M. M. (2018). Social and ecological correlates of space use patterns in Bwindi mountain gorillas. American Journal of Primatology. doi: 10.1002/ajp.22754.

Stowe, K. A. Marquis, R. J., Hochwender, C. G., Simms, E. L. (2000). The evolution ecology of tolerance to consumer damage. Annual review of ecology and systematics, 31(2000), pp. 565595.

Strauss, S. Y. and Agrawal, A. A. (1999). The ecology and evolution of plant tolerance to herbivory. Tree, 14(5), pp. 179-185.

Tiffany, K. M. (2004). The effects of herbivory and pollen limitation on declining population of trillium grandiflorum. Ecological Applications, 14(3), pp. 915-928.

VanWinkle W. (1975). Comparison of several probabilistic home-range models. J.Wildl. Manag. 39, 118. (doi:10.2307/3800474).

Vedder, A. L. (1984). Movement Patterns of a Group of Free-ranging Mountain Gorillas ( Gorilla gorilla beringei ) and Their Relation to Food Availability. American Journal of Primatology, 7, pp. 73-88.

Vesk, P. A. and Mark, W. (2001). Predicting plant species' responces to grazing. Journal of Applied Ecology, 38, pp. 897-909. doi: 10.1046/j.1365-2664.2001.00646.x.

Vickers, A. D. and Palmer, S. C. F. (2000). The influence of canopy cover and other factors upon the regeneration of Scots pine and its associated ground flora within Glen Tanar National Nature Reserve. Forestry, 73(1), pp. 38-19. 
Watts, D. P. (1984). Composition and variability of mountain gorilla diets in the central Virungas. American Journal of Primatology 7, pp.323-356.

Watts, D. P. (1987). Effects of mountain gorilla foraging activities on the productivity of their food plant species. African Jounal of Ecology, 25, pp. 155-163.

Watts, D. P. (1991). Strategies of Habitat Use by Mountain Gorillas. Folia Primatol, 56, pp. 116.

Watts, D. P. (1998a). Long-Term Habitat Use by Mountain Gorillas ( Gorilla gorilla beringei ). 1 . Consistency , Variation, and Home Range Size and Stability. International Journal of Primatology, 19(4), pp. 651-680.

Watts, D. P. (1998b). Long-Term Habitat Use by Mountain Gorillas ( Gorilla gorilla beringei ). 2 - Reuse of Foraging Areas in Relation to Resource Abundance, Quality, and Depletion. International Journal of Primatology, 19(4), pp. 681-702.

Weber, W. (1987). Ruhengeri and its resources: an environmental profile of the Ruhengeri Prefecture.

Whittaker, R. H. (1965). Branch Dimensions and Estimation of Branch Production. Ecology, 46(3), pp. 365-370.

Worton BJ. 1989. Kernel methods for estimating the utilization distribution in home-range studies. Ecology 70:164-168. 